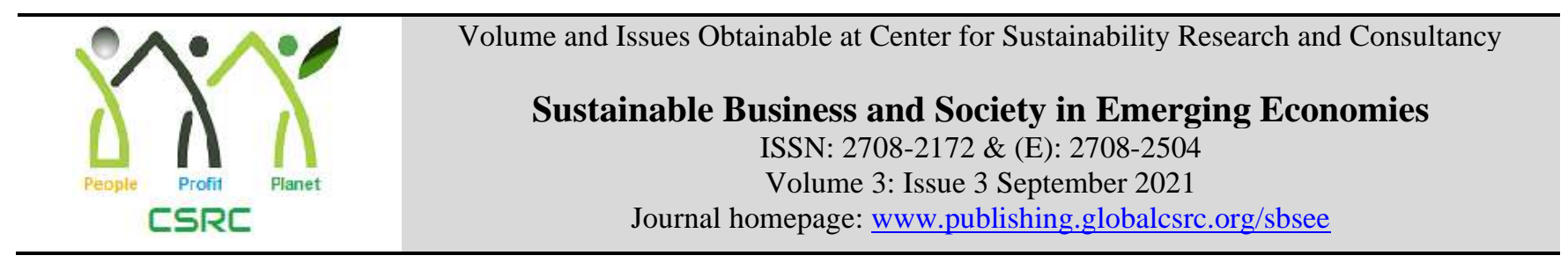

\title{
An Assessment of Financial Stability of Textile Sector of Pakistan: An Altman Z Score Approach
}

*Peeral Chandio, Mehran University of Engineering \& Technology, Jamshoro, Pakistan Arifa Bano Talpur, Mehran University of Engineering \& Technology, Jamshoro, Pakistan

*Corresponding author's email address: peeral13te54@gmail.com

\begin{tabular}{l}
\hline ARTICLE DETAILS \\
\hline History \\
Revised format: Aug 2021 \\
Available Online: Sep 2021 \\
\hline Keywords \\
Textile, Stability, Bankruptcy \\
Financial Ratios, Altman Z- \\
Score.
\end{tabular}

\section{JEL Classification} G10, G19

\section{OPEN ACCESS}

ABSTRACT

Purpose: The study purpose is to examine the financial stability of Pakistani textile enterprises. Investment towards textile is crucial to boost the textile sector's financial performance, which can be analyzed by adopting the model of Altman Z-score.

Design/Methodology/Approach: The Altman Z-score approach is a method, applied to analyze the financial stability of textile firms for seven years from 2013-2014 to 2019-2020 through the annual reports of textile firms which were taken from companies' website and PSX links. Quantitative analysis is done by MS-Excel using simple random sampling technique of secondary data of 10 firms taken from 5\% listed companies.

Findings: Finding of the study shows that financial performance of textile sector lies in all three zones of safe, grey and distress zones. $30 \%$ of textile sector falls in safe zone, $40 \%$ falls in grey while only $30 \%$ of textile sector of Pakistan falls in distress zone. Average result of textile sector of Pakistan is in grey zone, which shows the companies can get safe zone if they control required ratios.

Implications/Originality/Value: Result shows that textile firms of Pakistan may improve financial performance and stability because it lies in grey zone by controlling their financial ratios which are the part of Altman Z-Score model.

(C) 2021 The authors, under a Creative Commons AttributionNonCommercial- 4.0

Recommended citation: Chandio, P. and Talpur, A. B. (2021). An Assessment of Financial Stability of Textile Sector of Pakistan: An Altman Z Score Approach. Sustainable Business and Society in Emerging Economies, 3 (3), 309-318.

\section{Introduction}

Edward I. Altman created a model of Altman Z-Score in 1968 as a way to predict bankruptcy or financial soundness (strength). This model can be utilized for the estimation of credit risk and bankruptcy (corporate defaults) of any company. It is very beneficial for the investors in making decisions if they need to purchase or sell a particular company's stock. As a result, the study will employ Altman's Z-score to evaluate the textile industry's financial sustainability. (Ali, Rahman, \& Mahmud, 2016). Textile sector is a main source for growth of the economy. There is no other industry or service capable of boosting foreign 
earning and job generation economy especially efforts are made to develop the readymade clothing sector. Textile Industry of Pakistan had showed stability at global level during the last years. (Textile Industry in Pakistan, 2017-18).

The textile industry is Pakistan's main industry having huge contribution in trade growth, job generation and foreign exchange. Textile sector contributes 60\% in industrial sector to economy in 2019 (Textile Industry Division of Pakistan, 2019). The textile industry is the second largest in Pakistan's employment sector and the 8th biggest sector in exporting textile products in Asia, while it accounts for 8.5\% of GDP of Pakistan (Textile, Investment board, 2017-18). There are 423 textile industries working in the country and out of them 5\% are registered on the Pakistan Stock Exchange (Textile, Board of Investment, 2021). Bankruptcy analysis of any firm is so important for its managers and stakeholders. Investors are also interested in the financial position of organization to make decision for investment and other purposes. (Hussain, Ali, Ullah, \& Ali, 2014). According to Hapsoro \& Husain, 2019, sustainability of financial report matters because it attracts the investors to invest in the company. Altman Z-score technique helps investors to decide whether to buy or sell stock. It is also a useful tool to indicate a firm's distressed situation.

The companies which are financially strong always attract investors because they give them better dividend (Ozturk, \& Karabulut, 2018). The research aim is to check the stability of financial soundness of the textile sector of Pakistan. The model of Altman Z-Score has been applied to assess textile firms in Pakistan and provide a useful measure to analyze the sustainability and risk-free investment not only for firms but also for investors of this industry.

\section{Background of the Study}

Analysis of the companies is so important that like examine the performance of the company to know whether it's working perfect or some flaws are in it. Various outcomes of financial insolvency that took place in several countries in the world and having a short-term as well as long-term effect on the countries' economics condition that considered to be developing as well as developed countries showing in deficiency of investment and financial instrument which leads to instability to attain growth in financial sector leading to benefits for business ahead. (Aziz \& Dar, 2006).

So, for these problems are revealed by finding its solution for the betterment of the company that which factor affects the company more than other or factor has great role in making the firms stable. Many researchers have worked to analyze the performance of the companies. A few researchers have worked on stability in terms of financial health of Pakistan's textile sector.

If financial analysis of firms is not done in timely manner, then instability has probably to occur. The effects of insolvency are various which may affect company's financial position and investors in making decision for investment. (Altman, 1984).

\section{Literature Review}

The interrelation between liquidity and performance of corporate has long been a source of debate among academics of finance. From 2005 to 2014, the study examined the impact of ratios of liquidity on Pakistan's textile business performance and profitability. According to the findings, the performance and the profitability is favorable influenced by the current ratio but a very minor impact on performance effected by acid ratio but profitability was more influenced by acid ratio in the time of study (Sundas \& Butt, 2021). Hussain, et al investigated the impact of certain components on five Pakistan's textile industry through capital structure sample. They took secondary data of five industry companies between 2004 and 2014 from a review of the balance accounts of Pakistan Stock Exchange firms. Profitability is no impact on leverage ratio, while leverage ratio is connected to tangibility according to regression and correlation study using panel data. Leverage is also positively and significantly connected with business size and 
growth. Leverage has a negative relationship with return on equity (Hussain, Yu, \& Ling 2021). This article showed the Intellectual Capital (IC) effect on Indian textile sector's financial health by adopting the model of Public's Value-added intellectual capital coefficient (VAICTM). To measure the financial performance of company, they used three factors; Profitability (ROA), productivity (ATO) and return on equity (ROE) in this research by choosing reputed 81 textile firms. The findings revealed that efficiency of IC has a large and having positive connection with Indian textile industry's profitability and return on equity, with a negligible impact on productivity. This study also discovered that textile industry's profitability, productivity, or return on equity is not affected by Structural Capital Efficiency (SCE) in India (Shaneeb P, \& M Sumathy, 2021). The study evaluated the model of Z-Score classification performance in showing the Insolvency and other kinds of firm distressful conditions of firms. Using several variations of the original model, they analyzed the model of Z-Score performance of enterprises by selecting thirty-one European and 3 non-European nations. They applied the original model of Z-Score published by Altman in Corporate Financial Distress of private, manufacturing and non-manufacturing enterprises. Some proofs indicated that rival bankruptcy prediction model beats Z-Score model, The Foundation for Economic Education, as well as the Jenny and Antti Wihuri Foundation, provided financial help to Laitinen and Suvas. Laitinen also acknowledged the OP-Pohjola Group Research Foundation for funding a comprehensive international comparison; yet, it's difficult to generalize the conclusions of competing models. This research showed that the common work of model Z-Score quite fit for almost all countries with approximate predication accuracy of 0.75 and that an accuracy of classification may be increased more with beyond 0.90 through utilizing country-specific estimation with extra factors (Altman, E. I., Drozdowska. M. I., Laitinen. E. K., \& Suvas. A., 2017). The goal of Pervej and Anjum was to work on model of Altman Z-Score to estimate financial health for textile plants from Maharashtra from 200607 to 2015-16. This study summarized that the financial situation of public textile units were not safe and needs urgent attention of government and policy makers. Z-score of company shows a poor position, with bankruptcy score $(<1.23)$ and there is urgent need of proper remedial steps in order to enhance working capital, retained earnings, EBIT and sales to achieve target of safe zone (Above 2.99) (Pervej, \& Anjum, 2019). In 2018, Al-Manaseer \& Al-Oshaibat took 21 insurances enterprises which are registered on Amman Stock Exchange (ASE) to predict financial failure from 20011 to 2016. They employed method of statistical analysis and Multiple Linear Regression by working on the statistical assessment between variables; dependent and independent variables. According to them, Z-score model is the best way to evaluate the drawback (financial). The Z-score will be best tool not only for the inventors to invest but also the best for the managers to make policies. And they found the positive results for the financial failure of insurance companies (Al-Manaseer, \& Al-Oshaibat, 2018). Hussain, Ali, Ullah, \& Ali (2014) have deduced that model of Z-score for predicting bankruptcies of Pakistan is correct. This study examined the insolvency forecasting of the model of Z-Score with era of four years and concluded that the model of Altman Z-score is a good tool for the predictions of insolvency. Rashid, \& Abbas (2011) studied those financial ratios which are very effective in determining the bankruptcy of non-financial sectors (19962006). For predicting bankruptcy, they used twenty-four financial ratios; profitability, liquidity, leverages, and turnover ratios for 52 manufacturing companies of Pakistan. They applied multivariate analysis method approach. If the magnitude of Z-Score of company is greater than 2.99, then selected company will be non-bankrupt and if the magnitude of Z-score is below than 1.81, then the firm will be insolvent company. 26 companies were found to be bankrupt while 26 were found to be non-bankrupt. Awais, Hayat, Mehar, \& Hassan (2015) predicted the bankruptcy of textile sector by applying the Current Ratio and Z-Score. They examined the relationship between them by applying Paired Sample T-Test in SPSS and investigated that $Z$-score and Current Ratio relationship of 22 selected textile industries is significance positive. Comparing between time of 2008 and 2012, Pakistan's textile sector faced the most problems in 2008. The study recommended that a part of current ratio and the liquidity ratio be taken with Z-score for more accuracy for results. Khatik, \& Varghese (2013) examined financial position of the SAIL, so they calculated earning capacity; liquidity, and solvency. They stated that financial analysis is used for the analysis of an entity that with respect to investment that either firms is financially stable or not. Therefore, to measure soundness of steel authority of India limited (SAIL), they used ratio analysis technique by 
applying Correlation and Student $\mathrm{T}$ test. According to them, financial analysis is similar that when doctor examines the human body for his or her fitness.

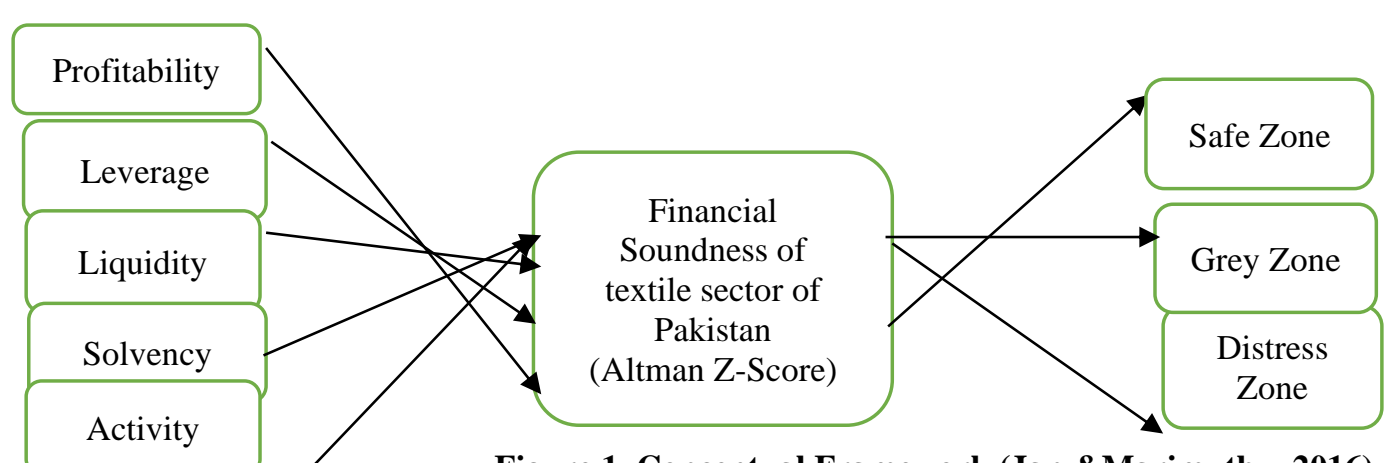

Figure 1. Conceptual Framework (Jan \&Marimuthu, 2016)

\section{Defining the Constructs \\ R1 (Liquidity Ratio)}

Liquidity shows the debtor's ability to pay off current debt's obligations. Its formula is Working capital divided by total assets.

\section{R2 (Profitability Ratio)}

It shows firm's capability to produce its earnings. According Altman Z-score its formula is such that total assets divide retained earnings. Profitability ratio describes how company is effective.

\section{R3 (Solvency Ratio)}

The productivity of assets of a firm before tax is measured by solvency ratio. In Solvency ratio, the total assets divide earnings before interest and tax of a firm. Firms depend upon its earning power and this ratio show firm's failure if liabilities exceed.

\section{R4 (Leverage Ratio)}

Volatility analysis shows that how much assets of firm decline in value which can be measured by dividing market is equity market value by total liabilities.

\section{R5 (Activity Ratio)}

Activity Ratio includes total assets turn over which measure the sale or revenue of the company to its total assets. Its formula is sales divided by total assets. It shows the firm's ability to produce sales over its total assets.

\section{Problem Statement / Research Gap}

Pakistan's textile industry is one of Pakistan's main industries, playing a key role in Pakistan's economy and influencing investors to invest in the sector. This research study has importance in terms of the sustainability of textile sector which specifically affects the investor's decisions towards the investment in this sector. Altman Z-score is best tool to evaluate the insolvency of Agricultural companies (Grushniene, 2016).

There are few studies that have worked on textile sector's sustainability in terms of bankruptcy among such as Awais, H., Hayat, F., Mehar, N., \& Hassan, U. W. (2015) studied the relationships between current ratio and Z-score model covering period from 2008 to 2012 and examined bankruptcy of textile firms of Pakistan. The Altman Z-Score will be the focus of this research and which will cover period from 20132014 to 2019-2020 fiscal years to fill this gap. The study is to analyze financial stability in Z- score Model to assess textile firms' soundness in three scales such as safe zone (>2.99), Grey Zone (from 1.81 to 2.99) and Distressful $(<1.81)$ that scales can help in the decision making of not only firms but also the investors of textile firms (Investopedia, 2021). 


\section{Scope of the Study}

This portion continues to describe the research scope of this study. Scope of the study is mentioned below:

1. Determining of financial performance of Pakistan's textile firms and listing the textile firms in safe, grey, and distress zones.

2. Examining the outcomes for the stability of textile firms of Pakistan.

\section{Importance of Study}

The model of Altman Z-Score is very useful method for performance indicators analysis of the firms' management to evaluate its performance according three zones. And it also helps investors to decide to buy or sell a particular stock through financial stability of company. Therefore, the analysis will alert the textile sector to make strategic decisions for the firm's sound position to maintain its financial stability and it may attract the investors to invest in the specific stock. Furthermore, the findings of this research may be helpful for business forecast, management of company, government policies, financial institutions, investors and stakeholders, and conduction of further research.

\section{Objectives of Study}

1. To investigate financial ratios of textile sector in Z-score model.

2. To assess the factors that affects the financial soundness of textile sector in Pakistan.

3. To come up with decision to sustain the performance of textile industry in terms of investment for investor.

Research Questions: To achieve the above-mentioned objectives, this research would explain the following research questions:

1. Does Altman Z-Score help textile firms and investors for making decision?

2. How Z-score help to analyze the soundness of textile sector?

\section{Hypothesis}

1. H0; There is a negative effect of profitability, liquidity, leverage, solvency, and activity ratios on soundness (Altman Z-Score) of textile firms.

2. H1; There is a positive effect of profitability, liquidity, leverage, solvency, and activity ratios on soundness (Altman Z-Score) of textile firms.

\section{Research Methodology}

This research is based on quantitative research. The data is secondary which will be taken from companies' websites and stock exchange official website. Ten listed textile firms will be selected to analyze their financial statements of seven years (2014-2020). This study is cross sectional study. The soundness of textile industries will be analyzed according to Altman Z-score measurement model with the help of MSExcel software (Pervej, \&Anjum, 2019). Individual company's yearly data and over all company's Altman Z-score will be assessed.

Altman Z-score predicts financial performance of any company. The Altman Z-score model is consisted of 5 financial ratios. It is very beneficial for the investors in making decisions if they need to purchase or sell a particular company's stock. In this study, above model is applied in textile industry to check its financial sustainability. Altman Z-score has ability to check the bankruptcy of textile firms. (Hussain, Ali, Ullah, \& Ali, 2014).

Altman Z-Score $=1.2 \mathrm{R}_{1}+1.4 \mathrm{R}_{2}+3.3 \mathrm{R}_{3}+0.6 \mathrm{R}_{4}+1.0 \mathrm{R}_{5}$

equation

- $\mathrm{R}_{1}=$ Working Capital / Total Assets

- $\mathrm{R}_{2}=$ Retained Earnings / Total assets

- $\mathrm{R}_{3}=\mathrm{EBIT} /$ Total Assets

- $\mathrm{R}_{4}=$ M.V of Equity / Total Liabilities

- $\mathrm{R}_{5}=$ Sales / Total Assets 
If magnitude of Z-Score is below 1.81, it means that selected organization is bankrupt, whereas companies Z-score value from 1.81 to 2.99 indicates that it could be headed for bankruptcy or can be in solid in next year, and if Z-score exceeds than 2.99 then organization is in solid position. To decide whether they purchase or sell stock, if the Altman Z-score value is greater than 2.99, investors are recommended to buy stock in other case, they may have to sell stocks if the value is below 1.81 or from 1.81 to 2.99 (Edward, 1968).

Research Design: This study is cross sectional study based on fiscal years from 2013-2014 to 2019-2020 of ten textile firms. In this study, financial analysis is done of each firm with each individual year. And finally, overall financial performance of seven years and textile sector of Pakistan is analyzed. This study is comprised of secondary data which is collected through online resource of each firm and Pakistan Stock Exchange (PSX) of seven years from 2013-2014 to 2019-2020. This study follows simple random sampling technique. Some data were extracted from online resources such as website of firms and PSX links. The sample selection size is primarily linked to the data analysis technique and the available resources. There are 423 textile industries working in the country and out of them 5\% (21) are registered on Pakistan Stock Exchange websites source covering from 2013-2014 to 2019-2020 fiscal years (Textile, Board of Investment). The data collected during the seven years cross-sectional time having was 10 samples (Secondary data of 10 companies are) taken from 5\% listed companies which are listed on Pakistan Stock Exchange. Percentage of sample size will be (10/21) 48\%.

\section{Data Analysis}

\begin{tabular}{|c|c|c|c|c|c|}
\hline Name of Company & Z-score & $\begin{array}{c}\mathrm{Z}<1.81 \\
\text { (Distress Zone) }\end{array}$ & $\begin{array}{c}1.81 \leq \mathrm{Z} \leq 2.99 \\
\text { (Grey Zone) }\end{array}$ & $\begin{array}{c}\text { Z > 2.99 } \\
\text { (Safe Zone) }\end{array}$ & Zone \\
\hline BTML & 3.9 & & & $\sqrt{ }$ & Safe \\
\hline GATML & 2.0 & & $\sqrt{ }$ & & Grey \\
\hline STML & 2.3 & & $\sqrt{ }$ & & Grey \\
\hline SCML & 3.5 & & & $\sqrt{ }$ & Safe \\
\hline TT & 3.3 & & & $\sqrt{ }$ & Safe \\
\hline CTML & 1.0 & $\sqrt{ }$ & & & Distress \\
\hline KML & 1.8 & $\sqrt{ }$ & & & Distress \\
\hline AHTML & 1.8 & $\sqrt{ }$ & & & Distress \\
\hline CFL & 2.4 & & $\sqrt{ }$ & & Grey \\
\hline NML & 2.4 & & $\sqrt{ }$ & & Grey \\
\hline Average & 2.44 & & $\sqrt{ }$ & & Grey \\
\hline
\end{tabular}

Table 1. Overall Altman Z-score of textile sector

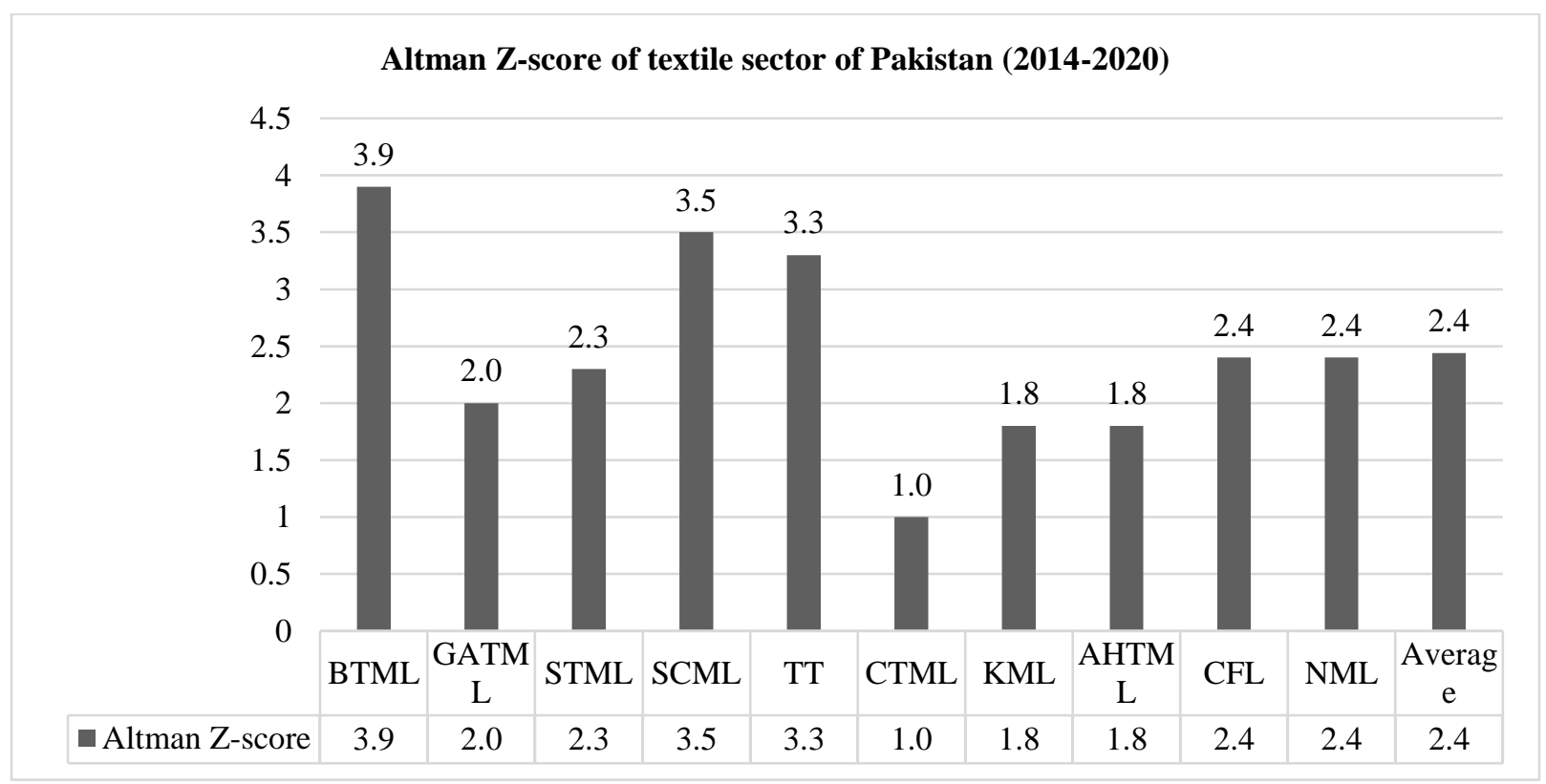

Figure 2. Bar graph of overall all financial performance of textile sector (2014-2020) 
The benchmark of Altman $\mathrm{Z}$ score for safe zone is greater than 2.99, and for grey zone is from 1.81 to 2.99 and for distress zone is less than 1.81. According figure 2 and table 1, out of ten textile firms, three textile firms CTML (1.0), KML (1.8), and AHTML (1.8) fall in distress zone, four textile firms; GATML (2.0), STML (2.4), CFL (2.4), and NML (2.4) were placed in grey zone which showed the average financial performance than other firms and these firms can improve them. And three companies; BTML (3.9), SCML (3.5), TT (3.3) were placed in safe zone which shows that these firms are financially stable and can attract the investors. Overall result of textile sector is in grey zone, which means the companies may be bankrupt if their financial ratios were not controlled.

Financial Performance of textile in Pakistan

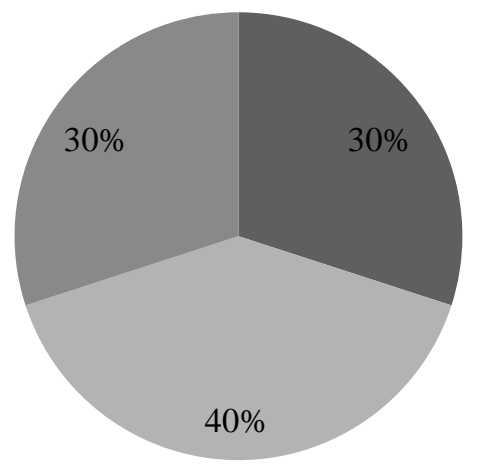

$\square$ Safe Zone $\quad$ Grey Zone $\quad$ Distress Zone

Figure 3. Pie graph of financial performance of textile sector (2014-2020)

In percentage wise, the zone of textile is divided into three parts in pie graph figure 3. Above pie graph shows that $30 \%$ of textile sector of Pakistan which are BTML, SCML, and TT textile firms fall in safe zone, $40 \%$ textile of Pakistan which are GATML, STML, CFL, and NML textile firms fall in grey while $30 \%$ as CTML, KML, and AHTML firms of textile sector of Pakistan fall in distress zone.

Altman Z-Score (Dependent Variable)

Least Square (Method)

Date: 11/05/2021, Time: 12:23

Sample size: 170 , Total Observations: 70

\begin{tabular}{|c|c|c|c|c|}
\hline Variable & Coefficient & Std. Error & t-statistics & Prob. \\
\hline R1 & 1.200004 & $1.43 \mathrm{E}-06$ & 838192.8 & 0.0000 \\
\hline $\mathrm{R} 2$ & 1.400000 & $1.93 \mathrm{E}-06$ & 724807.4 & 0.0000 \\
\hline R3 & 3.299993 & 8.64E-06 & 381890.3 & 0.0000 \\
\hline $\mathrm{R} 4$ & 0.600000 & 4.49E-07 & 1335874 & 0.0000 \\
\hline R5 & 0.99999 & $7.80 \mathrm{E}-07$ & 1281878 & 0.0000 \\
\hline $\mathrm{C}$ & $1.18 \mathrm{E}-06$ & $1.17 \mathrm{E}-06$ & 1.011144 & 0.3158 \\
\hline \multicolumn{2}{|c|}{ R-squared } & 1.000000 & Mean Dependent Variable. & 2.446159 \\
\hline \multicolumn{2}{|c|}{ Adjusted R-squared } & 1.000000 & S.D dependent Variable & 1.060038 \\
\hline \multicolumn{2}{|c|}{ S.E of regression } & $2.04 \mathrm{E}-06$ & Akaike info criterion & -23.28304 \\
\hline \multicolumn{2}{|c|}{ Sum squared resid } & $2.67 \mathrm{E}-10$ & Schwarz criterion & -23.09031 \\
\hline \multicolumn{2}{|c|}{ Log likelihood } & 820.9063 & Hannan-Wats on stat. & -23.20648 \\
\hline \multicolumn{2}{|c|}{ F-statistics } & $3.72 \mathrm{E}+12$ & Durbin-Wats on stat. & 1.894631 \\
\hline \multicolumn{2}{|c|}{ Prob. (f-statistics) } & 0.000000 & & \\
\hline
\end{tabular}

Table 2. Relationship of dependent and independent variables

Regression equation, $\mathrm{Y}=\mathrm{a}+\mathrm{b}(\mathrm{x})+\mathrm{e} \ldots(2)$

Table 2 proves the hypothesis of the study. It shows positive and direct relationship between all the independent variables such as R1 (Profitability), R2 (Liquidity), R3 (Solvency), R4 (Leverage), and R5 
(Activity) and dependent variable (Altman Z-Score). Summary of Altman Z-score results show the equation 1 showing R squared (R) 1.00000 and Adjusted R 1.00000 squared. T statistics is more than 2(standard) so its shows strong value and the value of Durbin-Watson value is 1. 894631.The equation shows $\mathrm{F}$ value is $3.72 \times 10^{\wedge} 12$ and prob. value 0.000 is statistically significant. The coefficient values of five ratios are R1 (1.200004), R2 (1.400000), R3 (3.299993), R4 (0.600000) and R5 (0.99999). Hence, all five ratios (profitability, liquidity, solvency, leverage and activity) are directly proportional to Altman Zscore. Hence $\mathrm{H} 1$; is proved that there is a positive relationship between profitability, liquidity, solvency, leverage and activity and Altman Z-score.

\section{Findings}

Altman Z-score of 10 textile companies has been calculated from seven years from 2013-2014 to 20192020 fiscal year. Alternative hypothesis is proved that textile sector of Pakistan falls that, here is a positive effect of profitability, liquidity, leverage, solvency, and activity ratios on soundness (Altman Z-Score). Safe zone which is 30\%, textile companies which lies in Safe zone are BTML, SCML, and TT. 40\%, textile sector of Pakistan falls in grey zone which are GATML, STML, CFL, and NML and only 30\% of textile sector of Pakistan falls in distress zone and textile companies which lay in distress zone are CTML KML, and AHTML. Overall result of financial performance textile sector was lying in grey; it means they are in average position which they can improve if the look after control liabilities and total assets.

\section{Conclusion of Study}

Atman Z-score uses financial ratios to give score to the textile firms to analyze its financial strength in term of three zones; Safe zone, Grey zone, and Distress zone. For achieving good results the ratios should be positive.

As per benchmark (Edward, 1968), the financial performance of BTML (3.9), SCML (3.5), and TT (3.3) were excellent with Altman Z score greater than 2.99 fall in safe zone. GATML (2.0), STML (2.3), CFL (2.4), and NML (2.4) textile firms showed average results having Altman Z score between 1.80 and 3.00 fall in grey zone, while KML (1.8), AHTML (1.8), and CTML (1.0) firms lying in distress zone have worst position among given textile companies because its Altman Z score is less than 1.81. Managers of Textile Company should make plan efficiently to increase the sales and decrease the cost because overall result showed that textile sector of Pakistan lies in grey zone which means either they should improve their performance or they can be in position to bankrupt in future otherwise.

\section{Limitations of the Study}

This study is carried on seven years of financial data of textile companies with spinning and composite mills of Pakistan by applying Altman Z-score. This model is consisting of only five ratios. Other models could be applied to check the financial position of the textile sector.

There are many other formulas of financial ratios of liquidity, profitability, solvency, leverage, and activity ratios, but according fixed model of Altman Z-score, its own standard financial ratios were used.

This Altman Z-score Model is used in textile companies and its can be used in other sectors to examine the financial health of sector.

\section{Suggestions for future work}

This study applied the model of Altman Z-score in textile sector. It could be applied in different sectors; agriculture sector, banking sector, cement factories, automobiles industries of Pakistan, etc. And the comparative analysis can be carried on textile sectors.

For analysis of financial performance of textile companies, other variables can be taken instead of liquidity, profitability, leverage, solvency, and activity ratios or some variables can be added like 
relationship between liquidity ratios with Altman Z-score model or profitability ratio and Altman Z score model.

\section{Reference}

Sundas, S \& Butt, M. (2021). Impact of liquidity on profitability and Performance: A Case of Textile Sector of Pakistan. International Journal of Commerce and Finance.

Hussain, S, Yu, \& Xiao Ling (2021). Determinants Affecting the Capital Structure Decision of A Firm (A Case Study of Textile Sector In Pakistan). International Journal of Management \& Entrepreneurship Research.

Shaneeb P, \& M Sumathy (2021). Impact of Intellectual Capital On Financial Performance In Indian Textile Industries. Academy of Accounting and Financial Studies Journal.

Altman, E. I., Drozdowska. M. I., Laitinen. E. K., \&Suvas. A. (2017). Financial Distress Prediction in an International Context: A Review and Empirical Analysis of Altman's Z-Score Model. Journal of International Financial Management \& Accounting 28:2 2017.

Pervej, M. D., \& Anjum, N. D., (2019). Application of Altman's Z score Model to Examine Financial Soundness of Public Sector Industry in Maharashtra- a Study of Selected Units. International Journal of Technical Research \& Science, Volume IV Issue VIII, August 2019 1-61-6. ISSN No.: 2454- 2024 (online)

Hapsoro, D., \& Husain, Z. F. (2019). Does sustainability report moderate the effect of financial performance on investor reaction? Evidence of Indonesian listed firms. International Journal of Business, 24(3), ISSN No: 1083-4346.

Ozturk, H., \&Karabulut, A. T. (2018). The Relationship Between Earnings-to-price, Current Ratio, Profit Margin and Return: An Empirical Analysis on Istanbul Stock Exchange. Accounting and Finance Research.

Al-Manaseer, S. R., \& Al-Oshaibat, S. D. (2018). Validity of Altman Z-Score Model to Predict Financial Failure: Evidence from Jordan. International Journal of Economics and Finance, Vol. 10, No. 8; 2018. ISSN 1916-971X, E-ISSN 1916-9728

Jaffari, A. A., \& Ghafoor, Z. (2017). Predicting Corporate Bankrupt in Pakistan a Comparative Study of Multiple Discriminant Analysis (MDA) and Logistic Regression. Research Journal of Finance and Accounting, ISSN 2222-1697 (paper) ISSN 2222-2847 (online), Vol. 8. No.3.2017

Grushniene, V. K. (2016). Altman Z-Score Model for Bankruptcy Forecasting Of the Listed Lithuanian Agricultural Companies. 5th International Conference on Accounting, Auditing, and Taxation (ICAAT 2016)

Jan, A., Marimuthu, M. (2016). Bankruptcy of Profile of Foreign versus Domestic Islamic Banks of Malaysia: A Post Crisis Period Analysis. International Journal of Economics and Finance Issues.

Lubawa, G. G., \& Louangrath, P. (2016). Using Altman Z-score to assess the financial effects of multiple loans on SMEs. International Journal of Research \& Methodology in Social Science, Vol. 2, No. 1, p.63 (Jan-Apr. 2016). ISSN 2415-0371 (online).

Ali, R. M., Rahman, M. M., \& Mahmud, S. M. (2016). Financial Soundness of Textile Industry: Altman Z-Score Measurement. Journal of Science and Technology, 8-17.

Awais, H., Hayat, F., Mehar, N., \& Hassan, U. W. (2015). Do Z-Score and Current Ratio have Ability to Predict Bankruptcy? Developing Country Studies, 30-36. Vol.5, No.13, ISSN 2224-607X (Paper) ISSN 2225-0565 (Online).

William, J., \& Nagamani, S. (2015). Textile Industry’s Performance and Financial Distress. International Journal of Accounting and Financial Management Research (IJAFMR), Vol. 5, Issue 5, Dec 2015, 17-28. ISSN (P): 2249-6882; ISSN (E): 2249-7994.

Rouf, A. M., Hasan, S. M., \& Ahmed, A. A. (2014). Financial reporting practices in the Textile Manufacturing Sectors of Bangladesh. ABC Journal of Advanced Research, Volume 3, No 2, ISSN 2304-2621(p); 2312-203X (e)

Hussain, F., Ali, I., Ullah, S., \& Ali, M. (2014). Can Altman Z-score Model Predict Business failures in Pakistan? "Evidence from Textile companies of Pakistan". Journal of Economics and Sustainable 
Development, Vol.5, No.13, 2014, ISSN 2222-1700 (Paper) ISSN 2222-2855 (Online)

Mizan, A., \& Hossain, M. M. (2014). Financial Soundness of Cement Industry of Bangladesh: An Empirical Investigation Using Z-Score. American Journal of Trade \& Policy.

Anand, M. D. (2014). A Study of Financial Analysis in Textile Sector, Journal of Business Management \& Social Sciences Research (JBM\&SSR), 80-86,Volume 3, No.6. ISSN No: 2319-5614.

Hussain, F., Ali, I., Ullah, S., \& Ali, M. (2014). Can Altman Z-Score Model Predict Business failure in Pakistan? Evidence from Textile companies of Pakistan. Journal of Economics and Sustainable development.

Ijaz, M., Hunjra, I. A., Zahid, H., Maqbool, A., \& Azam, I. R. (2013). Assessing the financial failure using the Z-score and current ratio: A case of sugar sector listed companies of Karachi Stock Exchange. World Applied Sciences Journal, 23(6), 863-870.

Khatik, S. K., \& Varghese, T. (2013). Financial analysis of steel authority of India limited. Research Journal (Madhya Bharti), Jan, 2013 ISSN No. 0974-0066.

Almazari, D. A. (2012). Financial Performance Analysis of the Jordanian Arab Bank by Using the DuPont System of Financial Analysis. International Journal of Economics and Finance, Vol. 4, No; 4 April 2012

Rashid, A., \& Abbas, Q. (2011). Predicting Bankruptcy in Pakistan. Theoretical and Applied Economics, Volume XVIII, No. 9(562), pp. 103-128.

Stakhanova, N., Basu, S., \& Wong, J., (2007). A Cost-Sensitive Model for Pre-emptive Intrusion Response Systems. Department of Computer Science Iowa State University Ames, IA 50011 USA

Aziz, M., \& Dar, H. (2006). Predicting corporate financial distress. Where we stand? Corporate Governance. The International Journal of Business in Society. 6(1), 18-33. https://doi.org/10.1108/14720700610649436

Gibson, C. H. (2001). Financial reporting and analysis using financial accounting information. Ohio; South Western CollegePublishing. 